\title{
POPULATION VARIABILITY IN QUERCUS BRANTII LINDL. BASED ON THE ACORN MORPHOMETRY AND CHOMPOSITION OF PHENOLIC COMPOUNDS
}

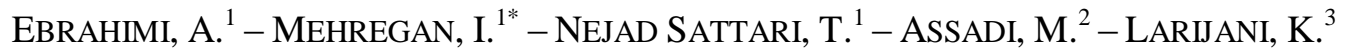 \\ ${ }^{1}$ Department of Biology, Science and Research Branch, Islamic Azad University, Tehran, Iran. \\ ${ }^{2}$ Research Institute of Forests and Rangelands, P. O. Box: 13185-116, Tehran, Iran. \\ ${ }^{3}$ Department of Chemistry, Science and Research Branch, Islamic Azad University, Tehran, \\ Iran. \\ *Corresponding author \\ e-mail:iraj@daad-alumni.de; imehregan@srbiau.ac.ir; phone: +98-21-4486-5327 \\ Islamic Azad University, Science and Research Branch, End of Sattari highway, Tehran \\ 147789385, Iran. \\ (Received 6 ${ }^{\text {th }}$ Dec 2015; accepted $3^{\text {rd }}$ May 2016)
}

\begin{abstract}
Persian Oak (Quercus brantii Lindl.) is one of the most important woody species of Zagros forests in western and southwestern Iran. In order to determine the variation of morphometry and total phenolic, flavonoid and tannin contents, ripen acorns from 27 populations of $Q$. brantii growing wild in nine regions of western and southwestern Iran were collected and examined. The amounts of total phenolic/tannin and flavonoid contents were determined by "Folin-Ciocalteu" and "Aluminum Chloride Colorimetric" methods, respectively. Significant differences in acorn morphometry were observed between the populations and regions, and the higher values of acorn morphometry belonged to four regions of Khuzestan province. Similarly, there also were significant differences in amounts of total phenolic, flavonoid and tannin contents between different populations and regions, and the higher amount of total phenolic, flavonoid and tannin contents were observed in populations from Khuzestan province. Different degrees of correlations were observed between the morphometery, total phenolics, flavonoids and tannins, and geographical and climatical factors. Cluster analysis and principle component analysis (PCA) based on the morphometric and phytochemical data resulted in detecting two major groups including: 1) populations from Khuzestan province, and 2) populations from adjacent provinces. Results of present study showed that morphology and amounts of total phenolic, flavonoid and tannin contents of Q. brantii acorns are significantly influenced by environmental factors of their original provenances.
\end{abstract}

Keywords: Persian oak, phenolic compounds, environmental factors

\section{Introduction}

The genus Quercus L. (English: “Oak”, Persian: "Baloot”) from the family Fagaceae has ca. 500 species of trees and shrubs in the Northern Hemisphere (except for the Arctic). Taxonomy of the genus has been controversial due to the widespread interspecies hybridization and introgression (Bajalan, 2013). The Zagros Mountain range, which is extended northwest-southeast from the border areas of eastern Turkey and northern Iraq to the southern Iran is a typical example of the continental variation of the Mediterranean climate pattern, with a snowy, cold winter and mild rainy spring followed by a dry summer and autumn (Frey and Probst, 1986). Quercus brantii Lindl. (Persian oak) is the most important tree species of the Zagros Mountains in Iran and covers more than $50 \%$ of the western forests of the country (Heydari et al., 2013). With average length of $1300 \mathrm{~km}$ and average width of $200 \mathrm{~km}$, Zagros forests are mainly 
consisted of Persian oak as dominant species mixed with other deciduous broad-leaved trees (Mehrnia et al., 2013).

The Oak forests of western Iran are also very important to the local communities from different aspects including soil and water conservation, byproducts and environmental values (Taleshi and Babarabi, 2013). Reports from the past decades show that ripen acorns of $Q$. brantii used to be the most important gathered food for the local communities of Zagros Mountains (Shiran et al., 2011). Chemical constitutions of acorns of different Quercus species have disinfectant, antioxidant and antimicrobial properties and the decoctions of acorn peels have been used to heal burns and cuts. (Şöhretoğlu et al., 2014; Borges et al., 2013; Salminen et al., 2004).

The most important chemical components of Oak acorns are related to the various classes such as saponins and phenolic compounds (including flavonoids and tannins) (Şöhretoğlu et al., 2014). It is shown that environmental factors such as altitude, latitude, precipitation, temperature, soil properties, and aspect would affect the synthesis of secondary metabolites. Amount of phenolic compounds can be influenced by developmental stage of the plant and different environmental factors such as soil composition, temperature, rainfall and ultraviolet radiation incidence, so that phenolic compounds and the other secondary metabolites show a chemical interface between plants and environment (Borges et al., 2013). Phytochemical compounds such as cuticular waxes, antifreeze polyols, and aromatics lead to acclimation to abiotic burdens, and some secondary metabolites such as aromatic alkaloids, furanocoumarins, flavonoids, phenylpropenoids and tannins may result in protection against both biotic and climatic effects (Alonso-Amelot et al., 2004).

\section{Review of literature}

Anatomical, morphological and chemical markers, enzyme activity indicators and DNA marker techniques are widely used to demonstrate the high variability and polymorphism in different Quercus species (Galván et al., 2012). Reports on the variability of chemical composition of oak acorns at the population-level are few (Galván et al., 2012; Brookes and Wigston, 1979; Shahian-Jahromi, 1999). Brookes and Wigston (1979) found that acorn shape and size and amounts of different element (N, P, $\mathrm{K}, \mathrm{Ca}, \mathrm{Mg}$ and $\mathrm{Na}$ ) contents are unreliable discriminants between $Q$. petraea (Matt.) Liebl., Q. robur L. and their hybrids. Galván et al. (2012) found negative correlations between morphometric characteristics of the acorn with the altitude in different populations of $Q$. ilex L. Despite the fact that chemical composition of different oak organs could be affected by environmental factors, variation of phenolic compounds might be useful in taxonomy of different Quercus species (Shahian-Jahromi, 1999). Singh and Todaria (2012) showed that nutrient composition of leaves in $Q$. semecarpifolia $\mathrm{Sm}$. is correlated to seasonal changes and also altitude. Salminen et al. (2004) demonstrated a seasonal variation in the phenolic contents of $Q$. robur's leaves. In $Q$. variabilis Blume seedlings, variation of nutrients and carbohydrates are related to environmental factors (Lei et al., 2013). Martin-StPaul et al. (2012) observed different degrees of photosynthetic sensitivity to drought among the populations of $Q$. ilex during a rainfall gradient. Morphology and chemical contents of leaves taken from different species of oak might be affected by a rainfall gradient. It is suggested that each species has a different mechanism to cope with water shortage, which is related to its structure and habit (Castro-Díez et al., 1997). Quantity of the secondary metabolites changes 
under drought stress in seedlings of $Q$. brantii, $Q$. infectoria Oliv. and $Q$. libani Oliv. (Nazari et al., 2013). Significant differences were also found in quality and quantity of protein profile of the acorns in different populations of Q. ilex (Galván et al., 2011).

In this work we first aim to evaluate the amounts of total phenolic, flavonoid and tannin contents of acorns collected from different populations of $Q$. brantii growing wild in SW Iran. Beside the chemical evaluations, some morphologic characters will also be measured. Finally, we aim to find the possible correlations between chemical contents of acorns and morphometric data, and also different ecological factors.

\section{Material and methods}

\section{Plant materials}

This study was performed on the acorns collected from 27 populations of the Persian oak (Q. brantii) growing wild in nine different regions of SW Iran. These materials were from provinces Lorestan (region KHA), Khuzestan (regions ALG, GOL, MOG, $\mathrm{BAB}$, and EMA), Chaharmahal and Bakhtiari (region MON), Kohgiluyeh and BoyerAhmad (region DIS) and Fars (region BAA) (Fig. 1). Geographical coordinates, altitude, aspect, average annual precipitation and average annual temperature corresponding to each region are presented in Table 1. Collection of acorns was carried out in three altitudes (low, middle and high) in each site during the autumn 2014. Each population was represented by at least 5 trees (individuals) with at least $50 \mathrm{~m}$ distance from each other.

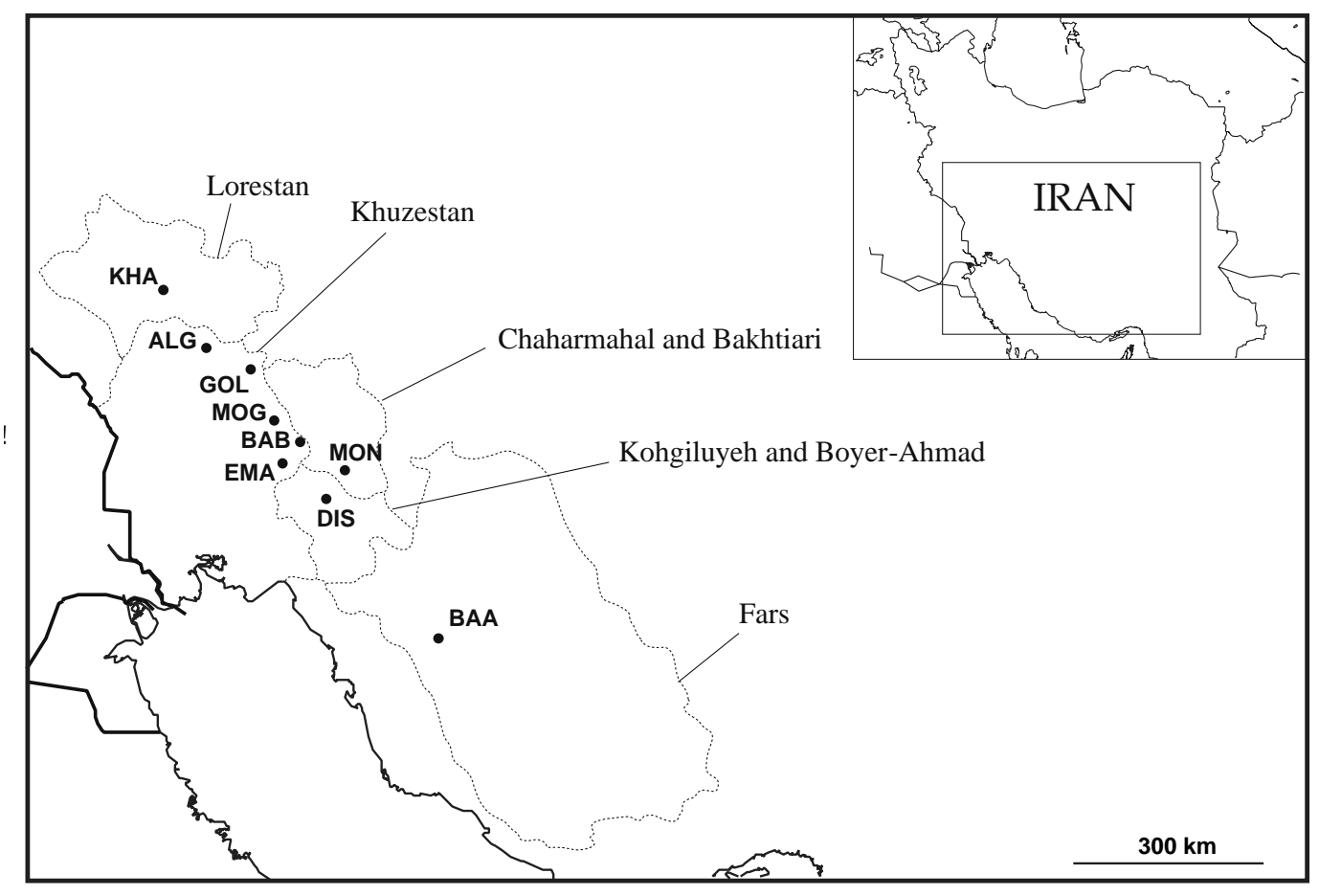

Figure 1. Map of Iran indicating localities of collected plant material. Each point represents the region in which three populations are collected (further details in Table 1).

Abbreviations: GOL, Golzar; EMA, Emamzadeh-Abdollah; BAB, Baloot-Boland; MOG, Mongasht; ALG, Alvar-Garmsiri; DIS, Dishmook; MON, Monj; KHA, Khorram-Abad; BAA, Barm-Arjan. 
Table 1. Geographical and climatic details of 27 populations of Quercus brantii collected for this study.

\begin{tabular}{|c|c|c|c|c|c|c|c|c|c|}
\hline Pop & Reg. & Prov. & $A b r$. & Alt. & Lat. & Long. & Asp. & $A A P$ & $\overline{A A T}$ \\
\hline $\begin{array}{l}1 \\
2 \\
3\end{array}$ & Golzar & Khuzestan & GOL & $\begin{array}{c}850 \\
1350 \\
1600\end{array}$ & $\begin{array}{l}32^{\circ} 12^{\prime} 54.3^{\prime \prime} \\
32^{\circ} 11^{\prime} 9.3^{\prime \prime} \\
32^{\circ} 9^{\prime} 16.4^{\prime \prime}\end{array}$ & $\begin{array}{l}49^{\circ} 43^{\prime} 40.1^{\prime \prime} \\
49^{\circ} 42^{\prime} 46.2^{\prime \prime} \\
49^{\circ} 43^{\prime} 36.5^{\prime \prime}\end{array}$ & $\begin{array}{l}\text { South } \\
\text { West } \\
\text { East }\end{array}$ & 35.27 & 21.4 \\
\hline $\begin{array}{l}4 \\
5 \\
6\end{array}$ & $\begin{array}{c}\text { Emamzadeh } \\
- \\
\text { Abdollah }\end{array}$ & Khuzestan & EMA & $\begin{array}{l}1630 \\
1801 \\
2086\end{array}$ & $\begin{array}{l}31^{\circ} 24^{\prime} 46.1^{\prime \prime} \\
31^{\circ} 23^{\prime} 38.6^{\prime \prime} \\
31^{\circ} 23^{\prime} 2.1^{\prime \prime}\end{array}$ & 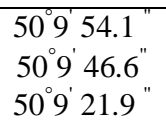 & $\begin{array}{c}\text { East } \\
\text { West } \\
\text { West }\end{array}$ & 132.6 & 27.5 \\
\hline $\begin{array}{l}7 \\
8 \\
9\end{array}$ & $\begin{array}{l}\text { Baloot- } \\
\text { Boland }\end{array}$ & Khuzestan & BAB & $\begin{array}{c}910 \\
1540 \\
2030\end{array}$ & $\begin{array}{l}31^{\circ} 4526.4^{\prime \prime} \\
31^{\circ} 41^{\prime} 51.1^{\prime \prime} \\
31^{\circ} 39^{\prime} 43.5^{\prime \prime}\end{array}$ & $\begin{array}{c}50^{\circ} 847.1^{\prime \prime} \\
50^{\circ} 18^{\prime} 25.7^{\prime \prime} \\
50^{\circ} 2326.6^{\prime \prime}\end{array}$ & $\begin{array}{l}\text { South } \\
\text { South } \\
\text { North }\end{array}$ & 34.27 & 19.02 \\
\hline $\begin{array}{l}10 \\
11 \\
12\end{array}$ & Mongasht & Khuzestan & MOG & $\begin{array}{c}950 \\
1285 \\
1621\end{array}$ & $\begin{array}{l}31^{\circ} 4754.9^{\prime \prime} \\
31^{\circ} 46^{\prime} 30.1^{\prime \prime} \\
31^{\circ} 46^{\prime} 15.7^{\prime \prime}\end{array}$ & $\begin{array}{c}49^{\circ} 59^{\prime} 9.3^{\prime \prime} \\
49^{\circ} 59^{\prime} 37.0^{\prime \prime} \\
50^{\circ} 023.7^{\prime \prime}\end{array}$ & $\begin{array}{c}\text { East } \\
\text { West } \\
\text { West }\end{array}$ & 35.27 & 21.4 \\
\hline $\begin{array}{l}13 \\
14 \\
15\end{array}$ & $\begin{array}{c}\text { Alvar- } \\
\text { Garmsiri }\end{array}$ & Khuzestan & $\overline{A L G}$ & $\begin{array}{c}650 \\
800 \\
1000\end{array}$ & $\begin{array}{c}32^{\circ} 5024.7^{\prime \prime} \\
32^{\circ} 49^{\prime} 45.4^{\prime \prime} \\
32^{\circ} 53^{\prime} 8.2^{\prime \prime}\end{array}$ & $\begin{array}{c}48^{\circ} 2234.5^{\prime \prime} \\
48^{\circ} 16^{\prime} 2.8^{\prime \prime} \\
48^{\circ} 15^{\prime} 53.0^{\prime \prime}\end{array}$ & $\begin{array}{l}\text { East } \\
\text { West } \\
\text { East }\end{array}$ & 20.26 & 26.55 \\
\hline $\begin{array}{l}16 \\
17 \\
18\end{array}$ & Dishmook & $\begin{array}{l}\text { Kohgiluyeh } \\
\text { and Boyer- } \\
\text { Ahmad }\end{array}$ & DIS & $\begin{array}{c}700 \\
1435 \\
2000\end{array}$ & $\begin{array}{c}31^{\circ} 14^{\prime} 29.1^{\prime \prime} \\
31^{\circ} 17^{\prime} 8.5^{\prime \prime} \\
31^{\circ} 16^{\prime} 20.8^{\prime \prime}\end{array}$ & $\begin{array}{l}50^{\circ} 18^{\prime} 0.2^{\prime \prime} \\
50^{\circ} 16^{\prime} 51.8^{\prime \prime} \\
50^{\circ} 22^{\prime} 12.1^{\prime \prime}\end{array}$ & $\begin{array}{l}\text { East } \\
\text { West } \\
\text { East }\end{array}$ & 372.3 & 25.0 \\
\hline $\begin{array}{l}19 \\
20 \\
21\end{array}$ & Monj & $\begin{array}{l}\text { Chaharmahal } \\
\text { and Bakhtiari }\end{array}$ & MON & $\begin{array}{l}1550 \\
1830 \\
2245\end{array}$ & $\begin{array}{l}31^{\circ} 30^{\prime} 27.1^{\prime \prime} \\
31^{\circ} 29^{\prime} 45.9^{\prime \prime} \\
31^{\circ} 30^{\prime} 10.3^{\prime \prime}\end{array}$ & $\begin{array}{l}50^{\circ} 3855.5^{\prime \prime} \\
50^{\circ} 365^{\prime} 3.8^{\prime \prime} \\
50^{\circ} 35^{\prime} 29.0^{\prime \prime}\end{array}$ & $\begin{array}{l}\text { South } \\
\text { West } \\
\text { West }\end{array}$ & 35.7 & 16.21 \\
\hline $\begin{array}{l}22 \\
23 \\
24\end{array}$ & $\begin{array}{l}\text { Khorram- } \\
\text { Abad }\end{array}$ & Lorestan & KHA & $\begin{array}{l}1162 \\
1420 \\
1874\end{array}$ & $\begin{array}{c}33^{\circ} 2618.1^{\prime \prime} \\
33^{\circ} 20.5^{\prime} 2^{\prime \prime} \\
33^{\circ} 17.29^{\prime \prime} 4^{\prime \prime}\end{array}$ & $\begin{array}{c}48^{\circ} 125.3^{\prime \prime} \\
48^{\circ} 25.18^{\prime} 9^{\prime \prime} \\
48^{\circ} 26.15^{\prime} 1^{\prime \prime}\end{array}$ & $\begin{array}{l}\text { South } \\
\text { East } \\
\text { East }\end{array}$ & 30.57 & 17.28 \\
\hline $\begin{array}{l}25 \\
26 \\
27\end{array}$ & Barm-Arjan & Fars & BAA & $\begin{array}{l}1249 \\
1655 \\
2101\end{array}$ & $\begin{array}{l}29^{\circ} 3346.6^{\prime \prime} \\
29^{\circ} 29^{\prime \prime} 28.7^{\prime \prime} \\
29^{\circ} 32^{\prime} 19.3^{\prime \prime}\end{array}$ & $\begin{array}{l}51^{\circ} 5119.5^{\prime \prime} \\
51^{\circ} 5822.4^{\prime \prime} \\
51^{\circ} 57^{\prime} 31.8^{\prime \prime}\end{array}$ & $\begin{array}{l}\text { North } \\
\text { North } \\
\text { West }\end{array}$ & 13.9 & 22.58 \\
\hline
\end{tabular}

Abbreviations: Pop., population; Reg., Region; Prov., Province; Abr., Abbreviation; Alt., Altitude; Lat., Latitude; Long., Longitude; Asp., Aspect; AAP, Average Annual Precipitation (mm), AAT, Average Annual Temperature ( $\mathrm{C}$ ).

Climatic Data were obtained from the Iran Agency of Meteorology (IRIMO) (http://www. irimo.ir).

\section{Acorn morphometry}

In order to measure size and weight, at least 10 healthy and fully-ripen acorns from each tree were selected and examined. Length (cupule excluded) and diameter at the widest part of acorn were measured by using a digital caliper (Mitutolyo). Fresh weight of acorns was measured on a digital precision balance (JL603-C, Mettler TOLEDO). 


\section{Preparation of acorn flour}

In order to remove the acorn's pericarp, longitudinal cuts were made using a sharp knife. This was repeated on 20-30 acorns collected from each tree. Cotyledons were converted to powder using a blade mill. The obtained powders were dried in a forced-air drier at $45^{\circ} \mathrm{C}$ for 48 hours, and then homogenized in a Waring Blender and sieved on a 1 $\mathrm{mm}$ mesh to get a fine homogeneous flour. Samples were kept in a refrigerator $\left(4^{\circ} \mathrm{C}\right)$ until chemical analyses.

\section{Preparation of the extracts}

Maceration method was used for extraction (Khoddami et al., 2013). $500 \mathrm{ml}$ hidroalcoholic $(\mathrm{MeOH})$ solvent was added to $100 \mathrm{~g}$ of each sample (acorn powder). Samples were kept at room temperature and away from sunlight for 72 hours. They were shaken and mixed several times and then were filtered. A rotary set was applied in order to thicker the extract. In order to remove the solvents, extracts were kept in freezedrier for 48 hours. Finally, the extracts were tightly covered and were kept in the refrigerator until analysis.

\section{Determination of total contents of phenolic compounds}

"Folin-Ciocalteau" method (Makkar et al., 1993) with slight modifications was used for determination of total contents of phenolic compounds. Suitable aliquots of the tannin-containing extract $(0.1,0.5$ and $1 \mathrm{ml}), 2.5 \mathrm{ml}$ of the diluted Folin-Ciocalteu reagent (10:1 ratio) and then $2 \mathrm{ml}$ of the $7.5 \%$ Sodium carbonate solution were added in tubes. After shaking the tubes on vortex and incubating for 2 hours, absorbance of their contents were recorded at $765 \mathrm{~nm}$ on a Spekol spectrophotometer (Analytik, Jena). The amount of total phenolics was calculated as tannic acid equivalent from the calibration curve (mg tannic acid equivalent/g dry extract). In order to prepare the calibration curve, concentrations of $0.02,0.04,0.06,0.08$ and $0.1 \mathrm{mg} / \mathrm{ml}$ of tannic acid were used. Experiments repeated three times for each sample.

\section{Determination of total tannin contents}

$1 \mathrm{ml}$ distilled water plus $1 \mathrm{ml}$ of the tannin-containing extract was added to $100 \mathrm{mg}$ Polyvinylpolypyrrolidone (PVPP) in a $100 \times 12 \mathrm{~mm}$ test tube. Then the tube was shaken, roomed for $15 \mathrm{~min}$ at $4^{\circ} \mathrm{C}$, was shaken again, and then centrifuged at $3000 \mathrm{~g}$ for $10 \mathrm{~min}$. The supernatant containing simple phenolic compounds was then collected and its content was measured spectrophotometry (Makkar et al., 1995). The difference between primary and secondary total phenolic contents (or non-tannin phenols) of each extract showed the content of tannins that express as tannic acid equivalent/g dry extract. Experiments repeated three times for each sample.

\section{Determination of total flavonoid contents}

"Aluminum Chloride Colorimetric" method as described by Chang et al. (Chang et al., 2002) with slight modifications was used to determine the total flavonoid contents. 2 $\mathrm{ml}$ methanolic extract was mixed with $2 \mathrm{ml} \mathrm{AlCl}_{3} \cdot 6 \mathrm{H}_{2} \mathrm{O} 2 \%$ and was incubated at room temperature for $15 \mathrm{~min}$. The absorbance of this mixture was measured at $430 \mathrm{~nm}$. Finally, the amount of total flavonoid as routine equivalent was calculated from the calibration curve ( $\mathrm{mg}$ routine equivalent/g dry extract). The calibration curve was 
prepared by using $0.0025,0.005,0.01,0.02,0.1$ and $0.5 \mathrm{mg} / \mathrm{ml}$ dilutions. Experiments repeated three times for each sample.

\section{Statistical analysis}

Kolmogorov-Smirnov test was used to determine the normality of frequency distributions. One-way ANOVA test were used to compare means of normal distributions (Galván et al., 2012). Duncan's test was used to analyses the differences in acorn morphometry and chemical data (Table 2). Pearson's correlation was carried out to test for correlation between acorn size, weight, chemical composition, climate and geographical data. Ward's cluster method using squared Euclidian distances was used for ascertainment of distances based on acorn morphometry and chemical data. Principal component analysis (PCA) was used for determine the most important factors of acorn for preparing of graph and compare with cluster analysis. Statistical analysis was carried out using SPSS v. 22 (IBM Inc, Chicago, IL).

Table 2. Studied characteristics of Quercus brantii acorn

\begin{tabular}{|l|c|}
\hline Studied characters & Abbreviation letters \\
\hline Total phenolic content & TPC \\
\hline Total flavonoid content & TFC \\
\hline Total tannin content & TTC \\
\hline Acorn weight & AW \\
\hline Acorn length & AL \\
\hline Acorn diameter & AD \\
\hline
\end{tabular}

\section{Results}

\section{Morphometry of acorn}

The results of morphometrical measurements of different oak populations are shown in Table 3 and Table 4. Acorn length ranged from $3.41 \pm 0.045 \mathrm{~cm}$ (reg. BAB, pop. 9, high altitude) to $6.38 \pm 0.032 \mathrm{~cm}$ (reg. BAB, pop. 8 , middle altitude) in populations. The mean of acorn length also ranged from $4.82 \pm 0.262 \mathrm{~cm}$ (reg. BAA) to $5.87 \pm 0.519 \mathrm{~cm}$ (reg. ALG) in regions. Acorn diameter ranged from $1.60 \pm 0.025 \mathrm{~cm}$ (reg. BAB, pop. 9, high altitude) to $2.74 \pm 0.025 \mathrm{~cm}$ (reg. EMA, pop. 5, middle altitude) in populations, and from $1.81 \pm 0.144 \mathrm{~cm}(\mathrm{reg} . \mathrm{MON})$ to $2.23 \pm 0.381 \mathrm{~cm}$ (reg. EMA) in regions. Acorn weight ranged from $3.63 \pm 0.025 \mathrm{~g}$ (reg. $\mathrm{BAB}$, pop. 9, high altitude) to $11.53 \pm 0.015 \mathrm{~g}$ (reg. GOL, pop. 2, middle altitude) in populations and from $5.49 \pm 0.492 \mathrm{~g}$ (reg. BAA) to 8.49 $\pm 2.37 \mathrm{~g}$ (reg. GOL) in regions. Statistically significant differences $(\mathrm{P}<0.05)$ were observed in acorn length, maximum diameter and weight between different populations.

Table 3. Acorn dimensions and weight of the 27 different populations of Quercus brantii collected from 9 regions in SW Iran. Minimum and maximum measurements are written in

Bold-italic and Bold, respectively.

\begin{tabular}{|c|c|l|l|l|}
\hline Reg. & Pop. & \multicolumn{1}{|c|}{$\boldsymbol{A L}(\boldsymbol{c m})$} & \multicolumn{1}{c|}{$\boldsymbol{A D}(\mathbf{c m})$} & \multicolumn{1}{c|}{$\boldsymbol{A W}(\mathbf{g})$} \\
\hline \multirow{3}{*}{ GOL } & 1 & $5.60 \pm 0.040 \mathrm{n}$ & $1.93 \pm 0.020 \mathrm{fgh}$ & $6.22 \pm 0.025 \mathrm{~h}$ \\
\cline { 2 - 5 } & 2 & $5.46 \pm 0.066 \mathrm{kl}$ & $2.58 \pm 0.030 \mathrm{o}$ & $\mathbf{1 1 . 5 3} \pm \mathbf{0 . 0 1 5} \mathrm{y}$ \\
\cline { 2 - 5 } & 3 & $4.75 \pm 0.055 \mathrm{~d}$ & $2.04 \pm 0.035 \mathrm{kl}$ & $7.72 \pm 0.021 \mathrm{o}$ \\
\hline
\end{tabular}




\begin{tabular}{|c|c|c|c|c|}
\hline \multirow{3}{*}{ EMA } & 4 & $5.25 \pm 0.045 \mathrm{hi}$ & $1.98 \pm 0.010 \mathrm{ij}$ & $7.33 \pm 0.030 \mathrm{~m}$ \\
\hline & 5 & $4.94 \pm 0.040 \mathrm{e}$ & $2.74 \pm 0.025 p$ & $9.73 \pm 0.025 \mathrm{w}$ \\
\hline & 6 & $4.86 \pm 0.066 \mathrm{e}$ & $1.97 \pm 0.020$ hij & $7.82 \pm 0.020 \mathrm{p}$ \\
\hline \multirow{3}{*}{$\mathrm{BAB}$} & 7 & $5.52 \pm 0.040 \mathrm{klmn}$ & $2.10 \pm 0.015 \mathrm{~m}$ & $8.13 \pm 0.025 \mathrm{r}$ \\
\hline & 8 & $6.38 \pm 0.032 q$ & $2.07 \pm 0.020 \mathrm{~lm}$ & $8.43 \pm 0.026 \mathrm{t}$ \\
\hline & 9 & $3.41 \pm 0.045 \mathrm{a}$ & $1.60 \pm 0.025 \mathrm{a}$ & $3.63 \pm 0.025 \mathrm{a}$ \\
\hline \multirow{3}{*}{ MOG } & 10 & $5.44 \pm 0.060 \mathrm{k}$ & $1.74 \pm 0.015 \mathrm{~d}$ & $7.83 \pm 0.031 \mathrm{p}$ \\
\hline & 11 & $5.33 \pm 0.055 \mathrm{j}$ & $2.02 \pm 0.020 \mathrm{k}$ & $9.43 \pm 0.025 \mathrm{v}$ \\
\hline & 12 & $5.05 \pm 0.055 \mathrm{f}$ & $1.70 \pm 0.055 \mathrm{~b}$ & $7.53 \pm 0.025 n$ \\
\hline \multirow{3}{*}{ ALG } & 13 & $6.06 \pm 0.060 \mathrm{p}$ & $1.83 \pm 0.030 \mathrm{e}$ & $6.04 \pm 0.040 \mathrm{f}$ \\
\hline & 14 & $6.36 \pm 0.045 \mathrm{q}$ & $2.04 \pm 0.035 \mathrm{kl}$ & $7.04 \pm 0.0251$ \\
\hline & 15 & $5.21 \pm 0.060 \mathrm{ghi}$ & $1.85 \pm 0.020 \mathrm{e}$ & $6.18 \pm 0.031 \mathrm{~g}$ \\
\hline \multirow{3}{*}{ DIS } & 16 & $5.50 \pm 0.055 \mathrm{klm}$ & $1.95 \pm 0.015 \mathrm{ghi}$ & $6.90 \pm 0.031 \mathrm{k}$ \\
\hline & 17 & $5.86 \pm 0.040 \mathrm{o}$ & $2.04 \pm 0.036 \mathrm{kl}$ & $8.39 \pm 0.031 \mathrm{~s}$ \\
\hline & 18 & $4.53 \pm 0.060 \mathrm{~b}$ & $1.72 \pm 0.020 \mathrm{~cd}$ & $4.29 \pm 0.031 \mathrm{~b}$ \\
\hline \multirow{3}{*}{ MON } & 19 & $5.29 \pm 0.045 \mathrm{ij}$ & $1.74 \pm 0.010 \mathrm{~d}$ & $6.61 \pm 0.015 \mathrm{j}$ \\
\hline & 20 & $5.58 \pm 0.034 \mathrm{mn}$ & $2.00 \pm 0.010 \mathrm{jk}$ & $10.70 \pm 0.015 \mathrm{x}$ \\
\hline & 21 & $5.35 \pm 0.050 \mathrm{j}$ & $1.69 \pm 0.010 \mathrm{c}$ & $6.63 \pm 0.015 \mathrm{j}$ \\
\hline \multirow{3}{*}{ KHA } & 22 & $5.15 \pm 0.035 \mathrm{~g}$ & $2.33 \pm 0.025 \mathrm{n}$ & $9.30 \pm 0.020 \mathrm{u}$ \\
\hline & 23 & $5.55 \pm 0.032 \mathrm{lmn}$ & $1.91 \pm 0.020 \mathrm{fg}$ & $7.89 \pm 0.010 q$ \\
\hline & 24 & $4.89 \pm 0.023 \mathrm{e}$ & $1.82 \pm 0.030 \mathrm{e}$ & $6.41 \pm 0.020 \mathrm{i}$ \\
\hline \multirow{3}{*}{ BAA } & 25 & $4.65 \pm 0.065 \mathrm{c}$ & $1.89 \pm 0.021 \mathrm{f}$ & $5.88 \pm 0.018 \mathrm{e}$ \\
\hline & 26 & $5.16 \pm 0.040 \mathrm{gh}$ & $1.83 \pm 0.020 \mathrm{e}$ & $4.84 \pm 0.015 \mathrm{c}$ \\
\hline & 27 & $4.64 \pm 0.050 \mathrm{c}$ & $1.81 \pm 0.030 \mathrm{e}$ & $5.75 \pm 0.017 \mathrm{~d}$ \\
\hline
\end{tabular}

Abbreviations: Reg., Region; Pop., Population; AL, Acorn length; AD, Acorn diameter; AW, Acorn weight; GOL, Golzar; EMA, Emamzadeh-Abdollah; BAB, Baloot-Boland; MOG, Mongasht; ALG, AlvarGarmsir; DIS, Dishmook; MON, Monj; KHA, Khorram-Abad; BAA, Barm-Arjan.

The descriptive statistics are presented in terms of the Mean $\pm S D$ (Standard Deviation). Mean values with the same letters indicate homogeneous subsets for $P \leq 0.05$ according to Duncan test.

Table 4. Acorn dimensions and weight of Quercus brantii collected from 9 regions in $S W$ Iran. Minimum and maximum measurements are written in Bold-italic and Bold, respectively.

\begin{tabular}{|l|l|l|l|}
\hline \multicolumn{1}{|c|}{$\boldsymbol{R e g}}$. & \multicolumn{1}{c|}{$\boldsymbol{A L}(\mathbf{c m})$} & \multicolumn{1}{c|}{$\boldsymbol{A D}(\mathbf{c m})$} & \multicolumn{1}{c|}{$\boldsymbol{A} \boldsymbol{W}(\boldsymbol{g})$} \\
\hline GOL & $5.27 \pm 0.397 \mathrm{a}$ & $2.18 \pm 0.302 \mathrm{c}$ & $\mathbf{8 . 4 9} \pm \mathbf{2 . 3 7} \mathrm{d}$ \\
\hline EMA & $5.02 \pm 0.182 \mathrm{a}$ & $\mathbf{2 . 2 3} \pm \mathbf{0 . 3 8 1} \mathrm{c}$ & $8.29 \pm 1.10 \mathrm{~cd}$ \\
\hline BAB & $5.10 \pm 1.32 \mathrm{a}$ & $1.93 \pm 0.243 \mathrm{ab}$ & $6.73 \pm 2.33 \mathrm{abc}$ \\
\hline MOG & $5.27 \pm 0.179 \mathrm{a}$ & $1.82 \pm 0.207 \mathrm{ab}$ & $8.26 \pm 0.884 \mathrm{~cd}$ \\
\hline ALG & $\mathbf{5 . 8 7} \pm \mathbf{0 . 5 1 9} \mathrm{b}$ & $1.91 \pm 0.102 \mathrm{ab}$ & $6.42 \pm 0.470 \mathrm{ab}$ \\
\hline DIS & $5.30 \pm 0.598 \mathrm{a}$ & $1.90 \pm 0.144 \mathrm{ab}$ & $6.53 \pm 1.79 \mathrm{ab}$ \\
\hline MON & $5.41 \pm 0.138 \mathrm{ab}$ & $\mathbf{1 . 8 1} \pm \mathbf{0 . 1 4 4} \mathrm{ab}$ & $7.98 \pm 2.04 \mathrm{bcd}$ \\
\hline KHA & $5.19 \pm 0.289 \mathrm{a}$ & $2.02 \pm 0.235 \mathrm{bc}$ & $7.87 \pm 1.25 \mathrm{bcd}$ \\
\hline BAA & $\mathbf{4 . 8 2} \pm \mathbf{0 . 2 6 2} \mathrm{a}$ & $1.84 \pm 0.043 \mathrm{ab}$ & $\mathbf{5 . 4 9} \pm \mathbf{0 . 4 9 2} \mathrm{a}$ \\
\hline
\end{tabular}

Abbreviations: Reg., Region; AL, Acorn length; AD, Acorn diameter; $A W$, Acorn weight; GOL, Golzar; EMA, Emamzadeh-Abdollah; BAB, Baloot-Boland; MOG, Mongasht; ALG, Alvar-Garmsir; DIS, Dishmook; MON, Monj; KHA, Khorram-Abad; BAA, Barm-Arjan.

The descriptive statistics are presented in terms of the Mean $\pm S D$ (Standard Deviation). Mean values with the same letters indicate homogeneous subsets for $P \leq 0.05$ according to Duncan test. 


\section{Phytochemical contents of acorn}

The results showed that amounts of total phenolic, flavonoid and tannin contents varied among populations and regions (Table 5 and Table 6). Amounts of total phenolic contents ranged from $210.18 \pm 8.24$ (reg. MON, pop. 21, high altitude) to $791.70 \pm 3.49 \mathrm{mg}$ tannic acid equivalent/g dry extract (reg. GOL, pop. 1, low altitude) in populations and from $324.17 \pm 95.16(\mathrm{reg}$. MON) to $727.93 \pm 78.99 \mathrm{mg}$ tannic acid equivalent/g dry extract (reg. GOL) in regions. Amounts of flavonoid contents ranged from $15.96 \pm 0.027$ (reg. BAA, pop. 27, high altitude) to $21.70 \pm 0.126 \mathrm{mg}$ routine equivalent/g dry extract (reg. MOG, pop. 11, medium altitude) in populations and from $16.60 \pm 0.517$ (reg. BAA) to $21.56 \pm 1.03 \mathrm{mg}$ routine equivalent $/ \mathrm{g}$ dry extract (reg. MOG) in regions. Total tannin contents ranged from $161.95 \pm 6.03$ (reg. MON, pop. 21 , high altitude) to $648.78 \pm 3.09 \mathrm{mg}$ tannic acid equivalent/g dry extract (reg. GOL, pop. 1, low altitude) in populations and from $277.46 \pm 93.05$ (reg. MON) to $581.55 \pm 67.38 \mathrm{mg}$ tannic acid equivalent/g dry extract (reg. GOL) in regions. Statistically significant differences $(\mathrm{P}<0.05)$ were observed in phytochemical contents between 27 populations (Table 5) and 9 regions (Table 6).

Table 5. Amounts of total phenolic, flavonoid and tannin contents in 27 population of Quercus brantii collected from 9 regions in SW Iran. Minimum and maximum measurements are written in Bold-italic and Bold, respectively.

\begin{tabular}{|c|c|c|c|c|}
\hline Reg. & Pop. & $T P C^{a}$ & $T F C^{b}$ & $T T C^{c}$ \\
\hline \multirow{3}{*}{ GOL } & 1 & $791.70 \pm 3.49 \mathrm{~m}$ & $21.42 \pm 0.252 \mathrm{kl}$ & $648.78 \pm 3.09 p$ \\
\hline & 2 & $755.56 \pm 70.35 \mathrm{~m}$ & $18.43 \pm 0.270 \mathrm{de}$ & $578.33 \pm 71.61 \mathrm{o}$ \\
\hline & 3 & $636.53 \pm 14.88 \mathrm{k}$ & $18.53 \pm 0.225 \mathrm{de}$ & $517.55 \pm 9.16 \mathrm{~lm}$ \\
\hline \multirow{3}{*}{ EMA } & 4 & $555.70 \pm 2.26 \mathrm{hi}$ & $18.10 \pm 0.055 \mathrm{~cd}$ & $439.81 \pm 4.36 \mathrm{~h}$ \\
\hline & 5 & $686.46 \pm 5.971$ & $21.36 \pm 0.600 \mathrm{kl}$ & $558.91 \pm 3.13 \mathrm{no}$ \\
\hline & 6 & $569.11 \pm 48.01$ hij & $18.45 \pm 0.360 \mathrm{de}$ & $462.79 \pm 33.57$ hijk \\
\hline \multirow{3}{*}{$\mathrm{BAB}$} & 7 & $596.86 \pm 22.24 \mathrm{ijk}$ & $19.44 \pm 0.120 \mathrm{hi}$ & $486.67 \pm 13.60 \mathrm{jkl}$ \\
\hline & 8 & $642.31 \pm 30.18 \mathrm{kl}$ & $19.75 \pm 0.312 \mathrm{i}$ & $531.31 \pm 23.66 \mathrm{mn}$ \\
\hline & 9 & $636.91 \pm 2.01 \mathrm{k}$ & $21.04 \pm 0.126 \mathrm{k}$ & $532.83 \pm 2.61 \mathrm{mn}$ \\
\hline \multirow{3}{*}{ MOG } & 10 & $617.17 \pm 8.03 \mathrm{jk}$ & $20.33 \pm 0.381 \mathrm{j}$ & $531.24 \pm 7.47 \mathrm{mn}$ \\
\hline & 11 & $605.80 \pm 5.73 \mathrm{jk}$ & $21.70 \pm 0.1261$ & $498.95 \pm 3.41 \mathrm{klm}$ \\
\hline & 12 & $617.17 \pm 7.5 \mathrm{jk}$ & $20.20 \pm 0.265 j$ & $484.53 \pm 5.27 \mathrm{ijkl}$ \\
\hline \multirow{3}{*}{ ALG } & 13 & $547.88 \pm 1.16 \mathrm{~h}$ & $18.80 \pm 0.190 \mathrm{efg}$ & $454.62 \pm 3.71 \mathrm{hij}$ \\
\hline & 14 & $558.50 \pm 0.645 \mathrm{hi}$ & $19.42 \pm 0.126 \mathrm{hi}$ & $469.56 \pm 0.805$ hijk \\
\hline & 15 & $645.85 \pm 30.47 \mathrm{kl}$ & $20.28 \pm 0.171 \mathrm{j}$ & $487.86 \pm 22.48 \mathrm{jkl}$ \\
\hline \multirow{3}{*}{ DIS } & 16 & $474.67 \pm 27.61 \mathrm{~g}$ & $21.63 \pm 0.3451$ & $402.98 \pm 21.38 \mathrm{~g}$ \\
\hline & 17 & $391.04 \pm 34.23 \mathrm{cde}$ & $18.64 \pm 0.198$ ef & $286.34 \pm 19.21 \mathrm{bc}$ \\
\hline & 18 & $367.01 \pm 3.91 \mathrm{bc}$ & $19.07 \pm 0.427 \mathrm{fgh}$ & $279.05 \pm 2.07 \mathrm{~b}$ \\
\hline \multirow{3}{*}{$\mathrm{MON}$} & 19 & $426.24 \pm 28.62 \mathrm{def}$ & $18.10 \pm 0.027 \mathrm{~cd}$ & $371.81 \pm 23.53 \mathrm{fg}$ \\
\hline & 20 & $336.09 \pm 0.853 \mathrm{~b}$ & $19.09 \pm 0.126 \mathrm{fgh}$ & $298.61 \pm 2.53 \mathrm{bcd}$ \\
\hline & 21 & $210.18 \pm 8.24 \mathrm{a}$ & $19.15 \pm 0.180 \mathrm{gh}$ & $161.95 \pm 6.03 \mathrm{a}$ \\
\hline \multirow{3}{*}{ KHA } & 22 & $432.02 \pm 0.645 \mathrm{efg}$ & $17.74 \pm 0.427 \mathrm{c}$ & $375.76 \pm 2.46 \mathrm{fg}$ \\
\hline & 23 & $375.95 \pm 48.93 \mathrm{bc}$ & $16.80 \pm 0.372 b$ & $321.67 \pm 41.09 \mathrm{cde}$ \\
\hline & 24 & $440.77 \pm 15.12 \mathrm{fg}$ & $18.10 \pm 0.344 \mathrm{~cd}$ & $380.74 \pm 12.72 \mathrm{fg}$ \\
\hline
\end{tabular}




\begin{tabular}{|c|c|c|c|l|}
\hline \multirow{3}{*}{ BAA } & 25 & $536.89 \pm 42.31 \mathrm{~h}$ & $16.74 \pm 0.180 \mathrm{~b}$ & $444.57 \pm 40.04 \mathrm{hi}$ \\
\cline { 2 - 5 } & 26 & $434.25 \pm 26.31 \mathrm{efg}$ & $17.10 \pm 0.120 \mathrm{~b}$ & $355.82 \pm 18.62 \mathrm{ef}$ \\
\cline { 2 - 5 } & 27 & $382.29 \pm 31.34 \mathrm{bcd}$ & $\mathbf{1 5 . 9 6} \pm \mathbf{0 . 0 2 7} \mathrm{a}$ & $326.81 \pm 23.26 \mathrm{de}$ \\
\hline
\end{tabular}

Abbreviations: Reg., Region; Pop., Population; TPC, Total phenolic content; TFC, Total flavonoid content; TTC, Total tannin content; GOL, Golzar; EMA, Emamzadeh-Abdollah; BAB, Baloot-Boland; MOG, Mongasht; ALG, Alvar-Garmsir; DIS, Dishmook; MON, Monj; KHA, Khorram-Abad; BAA, BarmArjan.

${ }^{a}$ mg tannic acid equivalent/g dry extract.

${ }^{b}$ mg routine equivalent/g dry extract.

${ }^{c}$ mg tannic acid equivalent/g dry extract.

The descriptive statistics are presented in terms of the Mean $\pm S D$ (Standard Deviation). Mean values with the same letters indicate homogeneous subsets for $P \leq 0.05$ according to Duncan test.

Table 6. Amounts of total phenolic, flavonoid and tannin contents of Quercus brantii collected from 9 regions in SW Iran. Minimum and maximum measurements are written in Bold-italic and Bold, respectively.

\begin{tabular}{|c|l|l|l|}
\hline Reg. & \multicolumn{1}{|c|}{$\boldsymbol{T P C}^{\boldsymbol{a}}$} & \multicolumn{1}{|c|}{$\boldsymbol{T F C}^{\boldsymbol{b}}$} & \multicolumn{1}{c|}{$\boldsymbol{T T C}^{\boldsymbol{c}}$} \\
\hline GOL & $\mathbf{7 2 7 . 9 3} \pm \mathbf{7 8 . 9 9} \mathrm{d}$ & $19.46 \pm 1.48 \mathrm{bc}$ & $\mathbf{5 8 1 . 5 5} \pm \mathbf{6 7 . 3 8} \mathrm{d}$ \\
\hline EMA & $603.76 \pm 66.84 \mathrm{c}$ & $19.30 \pm 1.59 \mathrm{bc}$ & $487.17 \pm 57.30 \mathrm{c}$ \\
\hline BAB & $625.36 \pm 28.54 \mathrm{c}$ & $20.08 \pm 0.757 \mathrm{~cd}$ & $516.94 \pm 26.52 \mathrm{c}$ \\
\hline MOG & $613.38 \pm 8.41 \mathrm{c}$ & $\mathbf{2 1 . 5 6} \pm \mathbf{1 . 0 3} \mathrm{d}$ & $504.91 \pm 21.28 \mathrm{c}$ \\
\hline ALG & $584.07 \pm 48.99 \mathrm{c}$ & $19.5 \pm 0.658 \mathrm{bc}$ & $470.68 \pm 18.38 \mathrm{c}$ \\
\hline DIS & $410.91 \pm 53.69 \mathrm{~b}$ & $19.78 \pm 1.43 \mathrm{bcd}$ & $322.79 \pm 61.93 \mathrm{ab}$ \\
\hline MON & $\mathbf{3 2 4 . 1 7} \pm \mathbf{9 5 . 1 6} \mathrm{a}$ & $18.78 \pm 0.520 \mathrm{~b}$ & $\mathbf{2 7 7 . 4 6} \pm \mathbf{9 3 . 0 5} \mathrm{a}$ \\
\hline KHA & $416.25 \pm 39.79 \mathrm{~b}$ & $17.55 \pm 0.670 \mathrm{a}$ & $359.39 \pm 35.62 \mathrm{~b}$ \\
\hline BAA & $451.14 \pm 74.21 \mathrm{~b}$ & $\mathbf{1 6 . 6 0} \pm \mathbf{0 . 5 1 7} \mathrm{a}$ & $375.73 \pm 58.70 \mathrm{~b}$ \\
\hline
\end{tabular}

Abbreviations: Reg., Region; TPC, Total phenolic content; TFC, Total flavonoid content; TTC, Total tannin content; GOL, Golzar; EMA, Emamzadeh-Abdollah; BAB, Baloot-Boland; MOG, Mongasht; ALG, Alvar-Garmsiri; DIS, Dishmook; MON, Monj; KHA, Khorram-Abad; BAA, Barm-Arjan.

${ }^{a}$ mg tannic acid equivalent/g dry extract.

${ }^{b}$ mg routine equivalent/g dry extract.

${ }^{c}$ mg tannic acid equivalent/g dry extract.

The descriptive statistics are presented in terms of the Mean $\pm S D$ (Standard Deviation). Mean values with the same letters indicate homogeneous subsets for $P \leq 0.05$ according to Duncan test.

\section{Correlation between the characters and geographical/climatical data}

The correlation between the morphometric/phytochemical measurements and geographical/climatical data are shown in Table 7. Acorn length, diameter and weight showed statistically significant negative correlation with longitude $(\mathrm{P} \leq 0.01$ or $\mathrm{P} \leq$ $0.05)$, and positive correlation with latitude range of seed collection $(\mathrm{P} \leq 0.01$ or $\mathrm{P} \leq$ $0.05)$. Also, acorn length and diameter showed statistically significant negative correlation with altitude $(\mathrm{P} \leq 0.01$ or $\mathrm{P} \leq 0.05)$. Acorn weight and diameter had a positive correlation $(\mathrm{P} \leq 0.01$ or $\mathrm{P} \leq 0.05)$ with Average Annual Precipitation (AAP). Except for the acorn weight $(\mathrm{P} \leq 0.01)$, the aspect showed no correlation with other factors (Table 7; Fig.2). 
Table 7. Correlation between the morphometric and phytochemical measurements and geographical/climatical data.

\begin{tabular}{|l|l|l|l|l|l|l|l|c|c|}
\hline & \multicolumn{3}{|c|}{$\begin{array}{c}\text { Morphometric } \\
\text { measurements }\end{array}$} & \multicolumn{4}{c|}{ Geographical data } & \multicolumn{2}{c|}{ Climate data } \\
\cline { 2 - 10 } & AW & AL & AD & Alt. & Lat. & Long. & Asp. & AAP & AAT \\
\hline AW & 1.00 & $0.442^{* *}$ & $0.727^{* *}$ & -0.078 & $0.257^{*}$ & $-0.257^{*}$ & $0.506^{* *}$ & $0.336^{* *}$ & -0.046 \\
\hline AL & $0.442^{* *}$ & 1.00 & $0.350^{* *}$ & $-0.520^{* *}$ & $0.321^{* *}$ & $-0.321^{* *}$ & 0.125 & -0.018 & -0.047 \\
\hline AD & $0.727^{* *}$ & $0.350^{* *}$ & 1.00 & $-0.243^{*}$ & $0.262^{*}$ & $-0.262^{*}$ & 0.140 & $0.224^{*}$ & 0.126 \\
\hline TPC & 0.167 & -0.004 & $0.304^{* *}$ & $-0.439^{* *}$ & $0.284^{*}$ & $-0.284^{*}$ & -0.126 & 0.053 & $0.386^{*}$ \\
\hline TFC & 0.158 & 0.216 & -0.003 & $-0.252^{*}$ & 0.164 & -0.164 & 0.173 & $0.422^{* *}$ & 0.142 \\
\hline TTC & 0.210 & 0.037 & $0.307^{* *}$ & $-0.448^{* *}$ & $0.275^{*}$ & $-0.275^{*}$ & -0.177 & 0.0240 & $0.327^{* *}$ \\
\hline
\end{tabular}

Abbreviations: AW, Acorn Weight; AL, Acorn Length; AD, Acorn Diameter; TPC, Total Phenolic Content; TFC, Total Flavonoid Content; TTC, Total Tannin Content; Alt., Altitude; Lat., Latitude; Long., Longitude; Asp., Aspect; AAP, Average Annual Precipitation (mm); AAT, Average Annual Temperature ( $\left.{ }^{\circ} \mathrm{C}\right)$.

Pearsons's correlation coefficient is indicated with level of significance $(P \leq 0.05$ and $P \leq 0.01)$. Minus sign (-) shows the negative and plus sign (+) shows the positive correlation between factors.

*Correlation is significant at the 0.05 level (2-tailed).

**Correlation is significant at the 0.01 level (2-tailed).
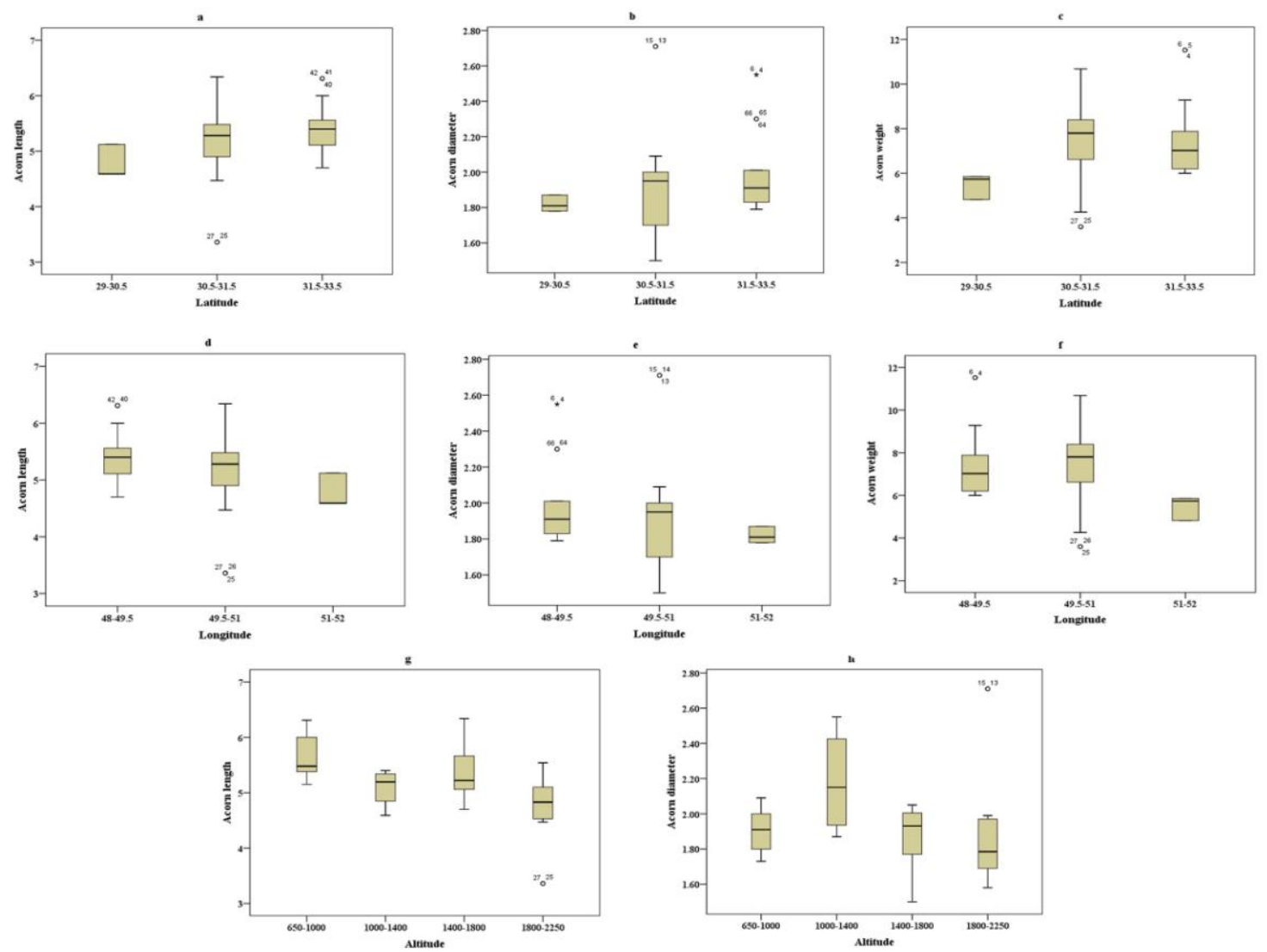

Figure 2. Correlation between acorn morphometry and geographical data. a, Acorn length and latitude; b, Acorn diameter and latitude; $\boldsymbol{c}$, Acorn weight and latitude; $\boldsymbol{d}$, Acorn length and longitude; $\boldsymbol{e}$, Acorn diameter and longitude; $\boldsymbol{f}$, Acorn weight and longitude; $\boldsymbol{g}$, Acorn length and altitude; $\boldsymbol{h}$, Acorn diameter and altitude. 
Total phenolic and tannin contents were positively correlated with latitude $(\mathrm{P} \leq$ $0.05)$, acorn diameter $(\mathrm{P} \leq 0.01)$, and Average Annual Temperature $(\mathrm{P} \leq 0.05)$, and negatively correlated with altitude $(\mathrm{P} \leq 0.01)$ and longitude $(\mathrm{P} \leq 0.05)$. Total flavonoid content was positively correlated with Average Annual Precipitation $(\mathrm{P} \leq 0.01)$ and negatively correlated with altitude $(\mathrm{P} \leq 0.05)$. It is showed that aspect did not affect the chemical contents (Table 7; Fig.3).
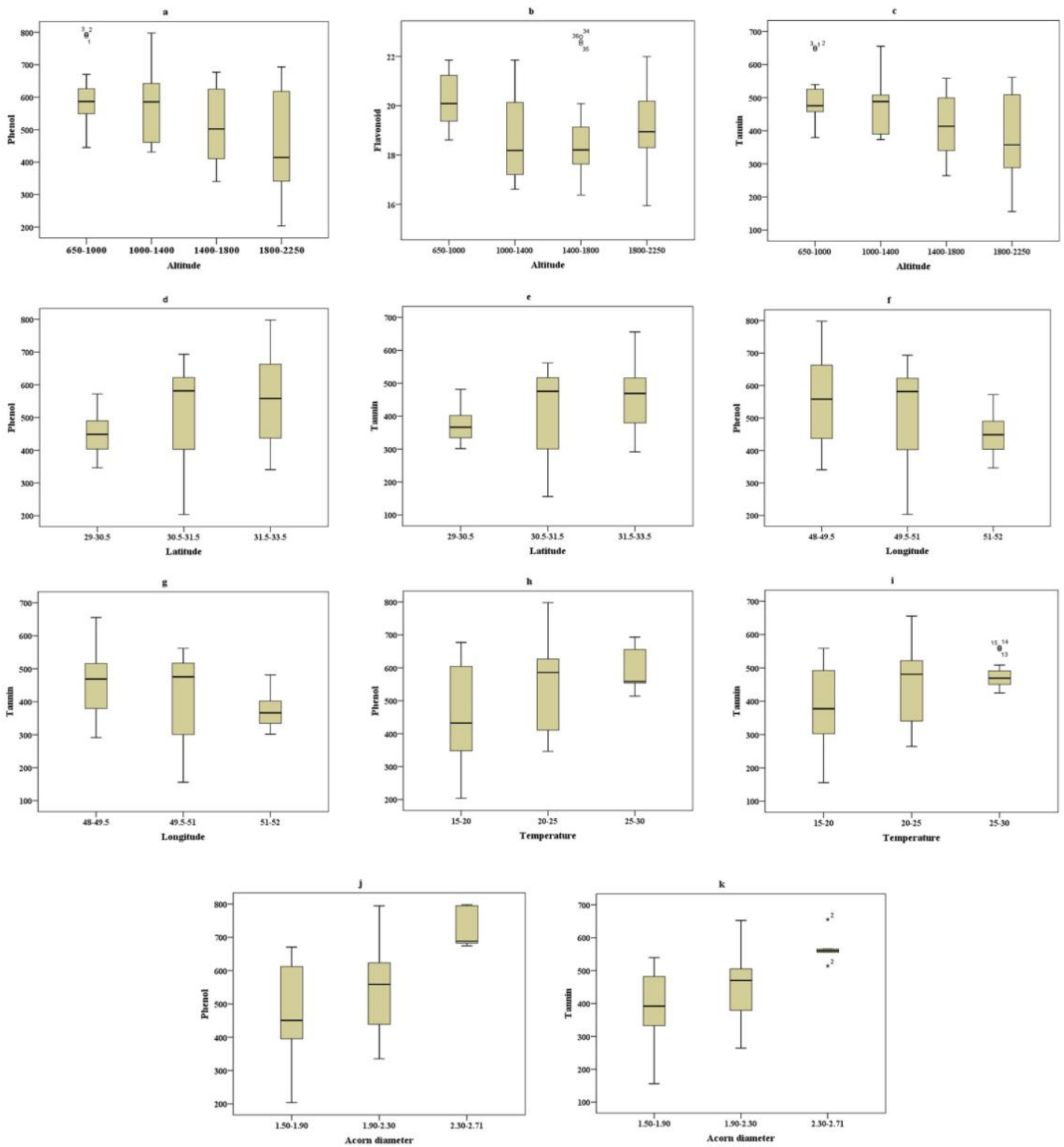

Figure 3. The correlation between the phytochemical and morphometric data and geographical/climatical data. $\boldsymbol{a}$, Phenolic content and altitude; $\boldsymbol{b}$, Flavonoid content and altitude; $\boldsymbol{c}$, Tannin content and altitude; $\boldsymbol{d}$, Phenolic content and latitude; $\boldsymbol{e}$, Tannin and latitude; $\boldsymbol{f}$, Phenol and longitude; $\boldsymbol{g}$, Tannin content and longitude; $\boldsymbol{h}$, Phenolic content and temperature; $\boldsymbol{i}$, Tannin content and temperature; $\boldsymbol{j}$, Phenolic content and acorn diameter; $\boldsymbol{k}$,

Tannin content and acorn diameter. 


\section{Cluster analysis}

A hierarchical dendrogram obtained from the cluster analysis of morphometric and phytochemical data of 27 populations using Ward method is shown in Fig. 4. Populations grouped into two main clusters $\mathrm{A}$ and $\mathrm{B}$ at an average distance value (ADV) of 18 . Cluster A is divided into two smaller sub-clusters A1 (consisted by populations of 3, 4, 6, $7,8,9,10,11,12,13,14,15)$ and $\mathrm{A} 2$ (consisted by populations of 1,2,5) at ADV of 3. Except for the population 25, all other populations belong to regions GOL, EMA, BAB, MOG and ALG (all from Khuzestan province). This cluster of populations showed a tendency to present higher values in acorn length, acorn diameter, acorn weight, and amounts of total phenolic, flavonoid and tannin contents. These populations grow in regions with an annual temperature ranging between 19.02 and $27.5^{\circ} \mathrm{C}$ and an altitude ranging between 650 and $2086 \mathrm{~m}$. The cluster B includes population 21 plus a nested subclade including populations 16, 17, 18, 19, 20, 23, 24, 26 and 27, all from regions DIS, MON, KHA, and BAA outside the provinces Khuzestan. They showed to have lower amount of phenolic compounds and similar values in total phenolic, flavonoid and tannin contents. These populations grow in regions with an annual temperature ranging between 16.21 and $25.0^{\circ} \mathrm{C}$ and an altitude ranging between 700 and $2245 \mathrm{~m}$.

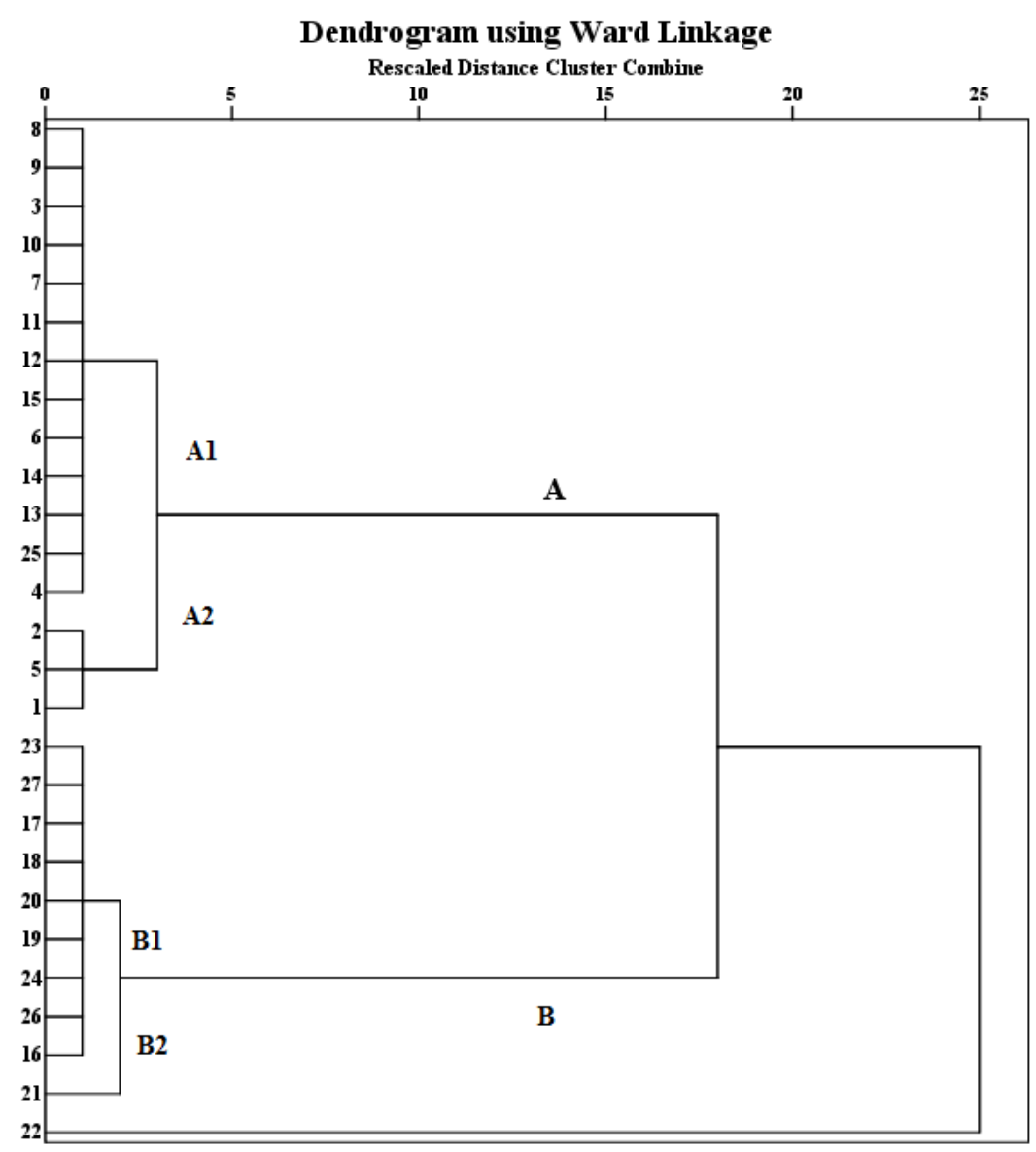

Figure 4. A hierarchical dendrogram obtained from the cluster analysis of morphometric and phytochemical data of 27 populations of Quercus brantii using Ward method with squared Euclidian distance. 1-3: GOL, Golzar; 4-6: EMA, Emamzadeh-Abdollah; 7-9: BAB, BalootBoland; 10-12: MOG, Mongasht; 13-15: ALG, Alvar-Garmsir; 16-18: DIS, Dishmook; 19-21: MON, Monj; 22-24: KHA, Khorram-Abad; 25-27: BAA, Barm-Arjan. 


\section{Principal component analysis (PCA)}

Principal component analysis (PCA) showed that the variation explained by the first component was mostly accounted for by variables related to the TPC (Total Phenolic Content) and TTC (Total Tannin Content) with $42 \%$ of total variation. On the other hand, these traits had the greatest impact in ordination. The second component explained $23 \%$ of the total variation, which was mostly due to the variation in AW (Acorn Weight) and AD (Acorn Diameter). Thus, these four traits had the greatest impact in the ordination. The PCA ordination based on first two components derived from principal components analysis could separate the populations on the base of acorn characteristics (Fig. 5). The symbols shown in the upper half of the graph illustrate the populations mainly growing in Khuzestan province and the signs in the lower half of the graph illustrate the populations mainly growing in other four provinces. As illustrated in Fig. 5, PCA results conform to those of cluster analysis.

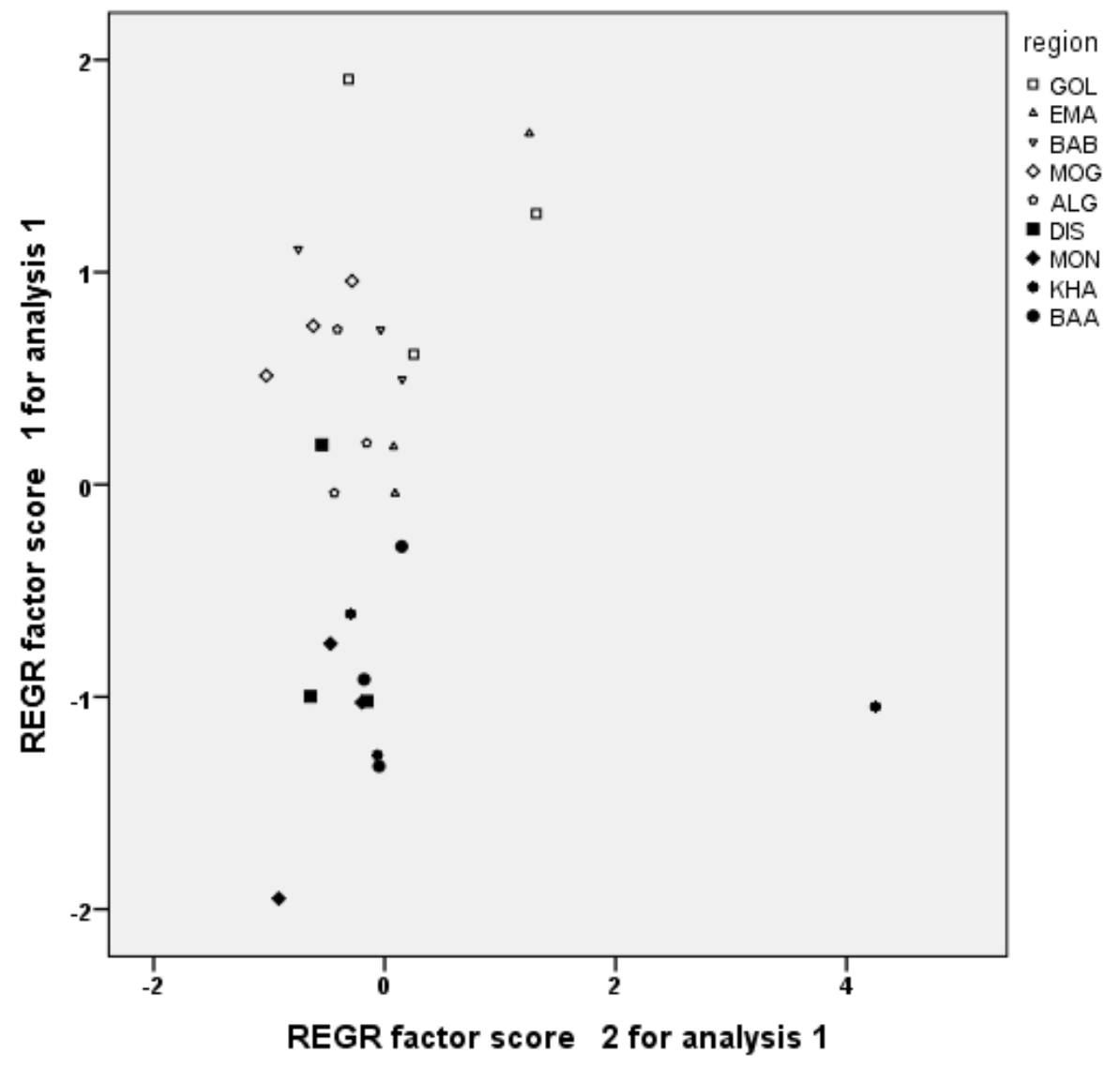

Figure 5. Ordination of 27 populations on the basis of first two component of PCA. Abbreviations: GOL, Golzar; EMA, Emamzadeh-Abdollah; BAB, Baloot-Boland; MOG, Mongasht; ALG, Alvar-Garmsiri; DIS, Dishmook; MON, Monj; KHA, Khorram-Abad; BAA, Barm-Arjan.

\section{Discussion}

We have observed variability in acorn morphometry and phytochemical contents of 27 populations of Persian oak ( $Q$. brantii) in southwestern Iran. The correlations between these variables and some geographical/climatical factors were also evaluated. 
Morphometrical characteristics of Persian oak acorn exhibited variation at the population's level (Table 3 and Table 4). These variations in acorn size were influenced by environmental factors (Table 7; Fig.2). Populations from the DIS, BAA, KHA, and MON had the smallest average acorn size, while Populations from the GOL, EMA, BAB, MOG, and ALG had the longest and broadest acorns. Populations growing in lowest altitudes showed the longest and broadest acorns; on the contrary, populations that grow in highest altitudes showed the smallest and thinnest acorns. Also, our study showed the positive correlation between acorn dimentions and latitude range of acorn collection. Variation in acorn morphometry at population's level had earlier been reported for some Quercus spp. In case of $Q$. ilex, acorn weight, length and diameter exhibited significant inverse correlation with altitude and significant positive correlation with latitude of acorn origin (Galván et al., 2012). Reports showed that acorn weight and length have significant inverse correlation with altitude of acorn origin of $Q$. glauca (Singh and Todaria, 2012). Furthermore, acorn morphometry of $Q$. suber also has showed a positive correlation with high latitudes of acorn origin of this species (Ramírez-Valiente et al., 2009). There is also a positive relationship between the acorn size of different American oaks and latitude (Aizen and Woodcock, 1992). Significant differences between the populations of $Q$. ilex based on their phytochemical compositions are shown in different studies (Galván et al., 2012; Galván et al., 2011). Phenolic compounds could be regarded as important markers in taxonomy of oaks (Shahian-Jahromi, 1999).

Based on our results, amounts of phenolic content of Persian oak exhibited variation and statistically significant differences at the population's level (Table 5). This is the first report of relationship between geographical/climatical data and acorn chemical composition of $Q$. brantii in Iran. It is shown that phenolic compounds of acorns in Persian oak populations are influenced by altitudinal, latitudinal, longitudinal, Average Annual Precipitation and Average Annual Temperature variation (Table 7; Fig.3). However, in this study, four populations from Khuzestan province (GOL, EMA, BAB, MOG, and ALG) showed a tendency toward presenting higher acorn size and phenolic compounds. The effect of some geographical/environmental factors on acorn chemical composition of $Q$. ilex (Galván et al., 2012) and $Q$. semecarpifolia (Singh and Todaria, 2012) is proved. Latitude variations play an important role in physiological performance of $Q$. variabilis plants (Lei et al., 2013). Tannins can help Q. brantii to resist under drought stress (Nazari et al., 2013). Different environmental conditions affect the phytochemical composition of different plant species (Borges et al., 2013; Lantemona et al., 2013; Bezerra et al., 2013; Mpofu et al., 2006; Ghafour et al., 2010; Alonso-Amelot et al., 2007; Hemati et al., 2012). Dissimilar to our results, a positive correlation exists between the tannins content of Glycyrrhiza glabra L. and mean annual precipitation, and a negative correlation exists between its tannins content and latitude (Oloumi and Hassibi, 2011). Similarly, mixed results were observed in Juglans regia L. (Ghasemi et al., 2011), Arnica montana (Spitaler et al., 2008) and Nepeta nuda (Kofidis and Bosabalidis, 2008). It seems that different species respons differently to the geographical and climatical factors. Furthermore, it is indicated that environmental stresses play important roles in genes expression, product and activity of enzymes involved in plant metabolism (Lantemona et al., 2013). The production of secondary metabolites in plants can be assumed as the result of plant development including metabolism changes, morphogenesis and differentiation. On the other hand, synthesis of secondary 
metabolites is the expression of a plant genome under developmental control. The relation of climatic factors with secondary metabolite production is necessary for understanding the biology of secondary metabolites in plants with protective role in relation to abiotic stresses such as temperature, water status, UV exposure, etc. (Oloumi and Hassibi, 2011). Differences in the phytochemical contents of the acorns could be related to some factors such as (1) weather conditions (raining and temperature), (2) the acorns physiological stages (ripening or germination) and (3) sanitary conditions (dryness, dampening, decaying, and attacks from pests) (Galván et al., 2012). The chemical structure of phenolic compounds provides the plant with a strong filtration power against the destructive ultra-violet (UV) light. So, the main importance of phenolic compounds may be related to the plants exposing to the excess solar high frequency radiation. Synthesis of phenolic and tannin compounds in plants can be affected by some factors such as the influence of environmental stress, disturbance, drought, and electromagnetic radiation, beside the main affecting factors like genetic determinants, physiological demands and evolution-controlled needs (Alonso-Amelot et al., 2007).

\section{Conclusion}

In conclusion, studied SW Iranian populations of $Q$. brantii, differ from each other in their acorn morphometry and the amounts of phytochemical contents. Acorn dimensions and weight and phenolic compounds showed to be significantly different between populations. Based on the results of this study, acorn size and weight and phenolic compounds are affected by biotic and abiotic factors including genetic structure of plants, plant growth and physiological conditions, geographical and climate conditions, and attacks from pests. Quercus brantii is a dominant species of oak in Zagros forests and further studies would help to provide efficient and useful conservation strategies for this species.

\section{REFERENCES}

[1] Aizen, M.A., Woodcock, H. (1992): Latitudinal trends in acorn size in eastern North American species of Quercus. - Canadian Journal of Botany 70: 1218-1222.

[2] Alonso-Amelot, M.E., Oliveros-Bastidas, A., Calcagno-Pisarelli, M.P. (2007): Phenolics and condensed tannins of high altitude Pteridium arachnoideum in relation to sunlight exposure, elevation, and rain regime. - Biochemical Systematics and Ecology 35 (1): 110.

[3] Alonso-Amelot, M.E., Oliveros, A., Calcagno-Pisarelli, M.P. (2004): Phenolics and condensed tannins in relation to altitude in neotropical Pteridium spp. A field study in the Venezuelan Andes. - Biochemical Systematics and Ecology 32 (11): 969-981.

[4] Bajalan, I. (2013): Leaves of Oak (Quercus brantii var. persica) as a rich source of phenolic compounds. - International Journal of Farming and Allied Sciences 2 (19): 734736.

[5] Bezerra, A.S., Nörnberg, J.L., Lima, F.O., Rosa, M.B., Carvalho, L.M. (2013): Climatic parameters and variation of phenolic compounds in barley. - Ciência Rural 43 (9): 15461552.

[6] Borges, L.L., Alves, S.F., Sampaio, B.L., Conceição, E.C., Bara, M.T.F., Paula, J.R. (2013): Environmental factors affecting the concentration of phenolic compounds in Myrcia tomentosa leaves. - Brazilian Journal of Pharmacognosy 23 (2): 230-238. 
[7] Brookes, P.C., Wigston, D.L. (1979): Variation of morphological and chemical characteristics of acorns from populations of Quercus petraea (Matt.) Liebl., Q. robur L.and their hybrids. - Watsonia 12: 315-324.

[8] Castro-Díez, P., Villar-Salvador, P., Pérez-Rontomé, C., Maestro-Martínez, M., Montserrat-Martí, G. (1997): Leaf morphology and leaf chemical composition in three Quercus (Fagaceae) species along a rainfall gradient in NE Spain. - Trees 11 (3): 127134.

[9] Chang, C.C., Yang, M.H., Wen, H.M., Chern, J.C. (2002): Estimation of total flavonoid content in propolis by two complementary colorimetric methods. - Journal of Food and Drug Analysis 10 (3):178-182.

[10] Frey, W., Probst, W. (1986): A synopsis of the vegetation in Iran. - In: Kurschner, H. (ed.), Wiesbaden, Germany.

[11] Galván, J.V., Novo, J.J.J., Cabreta, A.G., Ariza, D., García-Olmo, J., Navarro-Cerillo, R.M.N. (2012): Population variability based on the morphometry and chemical composition of the acorn in Holm oak (Quercus ilex subsp. ballota [Desf.] Samp.). European Journal of Forest Research 131 (4): 893-904.

[12] Galván, J.V., Valledor, L., Cerrillo, R.M.N., Pelegrín, E.G., Jorrín-Novo, J.V. (2011): Studies of variability in Holm oak (Quercus ilex subsp. ballota [Desf.] Samp.) through acorn protein profile analysis. - Journal of Proteomics 74 (8): 1244-1255.

[13] Ghafour, N., Hoshyar, A., Raad, M. (2010): Determination of some chemical constitutes of oak plants (Quercus spp.) in the mountain oak forest of Sulaimani governorate. Journal of Zankoy Sulaimani 13 (1): 129-142.

[14] Ghasemi, K., Ghasemi, Y., Ehteshamnia, A., Nabavi, S.M., Nabavi, S.F., Ebrahimzadeh, M.A., Pourmorad, F. (2011): Influence of environmental factors on antioxidant activity, phenol and flavonoids contents of walnut (Juglans regia L.) green husks. - Journal of Medicinal Plants Research 5 (7): 1128-1133.

[15] Hemati, Kh., Ghasemnezhad, A., Mashayekhi, K., Bashiri-Sadr, Z. (2012): Site effect on some important flavonoid compounds of Linden tree (Tilia platifolia L.). - Journal of Plant Production 19 (2): 141-148 [Farsi with English abstract].

[16] Heydari, M., Poorbabaei, H., Rostami, T., Begim-Faghir, M., Salehi, A., Ostad-Hashmei, R. (2013): Plant species in oak (Quercus brantii Lindl.) understory and their relationship with physical and chemical properties of soil in different altitude classes in the Arghavan valley protected area, Iran. - Caspian Journal of Environmental Sciences 11 (1): 97-110.

[17] Khoddami, A., Wilkes, M.A., Roberts, T.H. (2013): Techniques for analysis of plant phenolic compounds. - Molecules 18 (2): 2328-2375.

[18] Kofidis, G., Bosabalidis, A.M. (2008): Effects of altitude and season on glandular hairs and leaf structural traits of Nepeta nuda L. - Botanical Studies 49: 363-372.

[19] Lantemona, H., Abadi, A.L., Rachmansyah, A., Pontoh, J. (2013): Impact of altitude and seasons to volume, brix content, and chemical composition of Aren Sap in North Sulawesi. - Journal of Environmental Science, Toxicology and Food Technology 4 (2): $42-48$.

[20] Lei, J.P., Xiao, W., Liu, J.F., Xiong, D., Wang, P., Pan, L., Jiang,Y., Li, M.H. (2013): Responses of nutrients and mobile carbohydrates in Quercus variabilis seedlings to environmental variations using in situ and ex situ experiments. - Plos one 8 (4) e61192: 19.

[21] Makkar, H.P.S., Blümmel, M., Becker, K. (1995): Formation of complexes between polyvinyl pyrrolidones and polethylene glycols with tannins and their implications in gas production and true digestibility in in vitro techniques. - British Journal of Nutrition 73 (06): 897-913.

[22] Makkar, H.P.S., Blümmel, M., Borowy, N.K., Becker, K. (1993): Gravimetric determination of tannins and their correlations with chemical and protein precipitation methods. - Journal of the Science of Food and Agriculture 61 (2):161-165. 
[23] Martin-StPaul, N.K., Limousin, J.M., Rodríguez-Calcerrada, J., Ruffault, J., Rambal, S., Letts, M.G., Misson, L. (2012): Photosynthetic sensitivity to drought varies among populations of Quercus ilex along a rainfall gradient. - Functional Plant Biology 39 (1): 25-37.

[24] Mehrnia, M., Nejadsattari, T., Assadi, M., Mehregan, I. (2013): Taxonomic study of the genus Quercus L. Sect. Quercus in the Zagros forests of Iran. - Iranian Journal of Botany 19 (1): 62-74.

[25] Mpofu, A., Sapirstein, H.D., Beta, T. (2006): Genotype and environmental variation in phenolic content, phenolic acid composition, and antioxidant activity of hard spring wheat. - Journal of Agricultural and Food Chemistry 54 (4): 1265-1270.

[26] Nazari, M., Zolphaghari, R., Fayyaz, P. (2013): Secondary compositions variations under drough stress in Q.brantii, Q.infectoria and Q.libani seedling. - Journal of Forests and Wood Productes 66 (1): 1-14. [Farsi with English abstract].

[27] Oloumi, H., Hassibi, N. (2011): Study the correlation between some climate parameters and the content of phenolic compounds in roots of Glycyrrhiza glabra. - Journal of Medicinal Plants Research 5 (25): 6011-6016.

[28] Salminen, J.P., Roslin,T., Karonen, M., Sinkkonen, J., Pihlaja, K., Pulkkinen, P. (2004): Seasonal variation in the content of Hydrolyzable tannins, flavonoid glycosides, and proanthocyanidins in oak leaves. - Journal of Chemical Ecology 30 (9): 1693-1711.

[29] Shahian-Jahromi, M., Siami, A., Heydari, R. (1999): Morphological and chemotaxonomical evaluation of some Quercus species of Western Azerbaijan. M.Sc thesis, Department of Biology, University of Urmia, Iran [Farsi with English abstract].

[30] Shiran, B., Mashayekhi, S., Jahanbazi, H., Soltani, A., Bruschi, P. (2011): Morphological and molecular diversity among populations of Quercus brantii Lindl. in western forest of Iran. - Plant Biosystems 145 (2): 452-460.

[31] Singh, B., Todaria, N.P. (2012): Nutrients composition changes in leaves of Quercus semecarpifolia at different seasons and altitudes. - Annals of Forest Research 55 (2): 189196.

[32] Şöhretoğlu, D., Kuruüzüm-Uz, A., Simon, A., Patócs, T., Dékány, M. (2014): New secondary metabolites from Quercus coccifera L. - Records of Natural Products 8 (4): 323-329.

[33] Spitaler, R., Winkler, A., Lins, I., Yanar, S., Stuppner, H., Zidorn, C. (2008): Altitudinal variation of phenolic contents in flowering heads of Arnica montana cv. ARBO: a 3-year comparison. - Journal of Chemical Ecology 34 (3): 369-375.

[34] Taleshi, H., Maasoumi-Babarabi, M. (2013): Leaf morphological variation of Quercus brantii Lindl. along an altitudinal gradient in Zagros forests of Fars Province, Iran. European Journal of Experimental Biology 3 (5): 463-468. 